
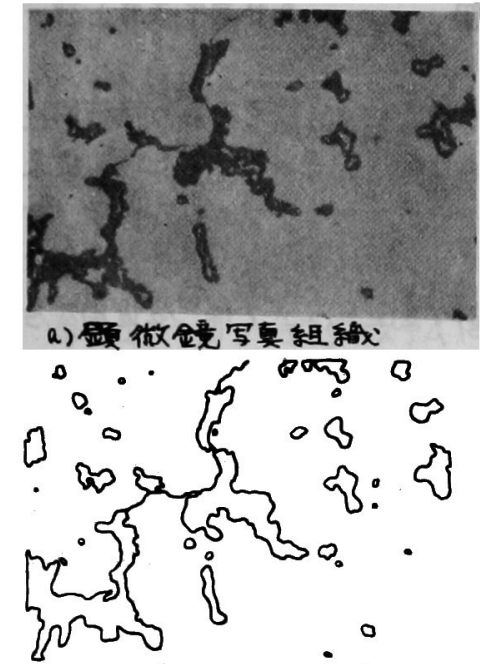

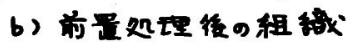

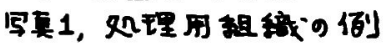

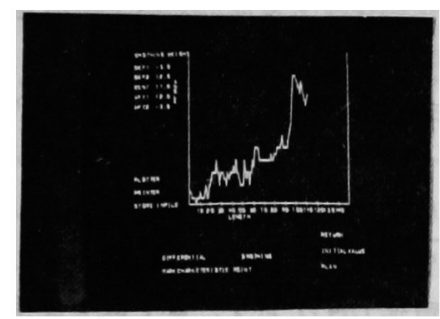

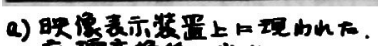

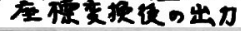

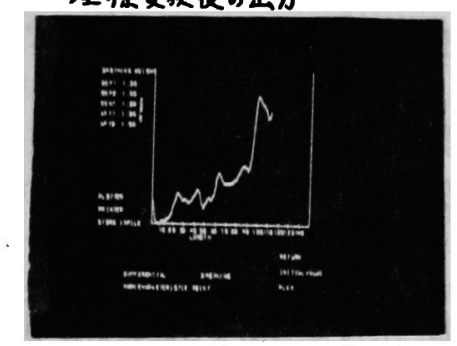

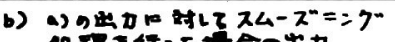

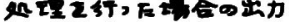

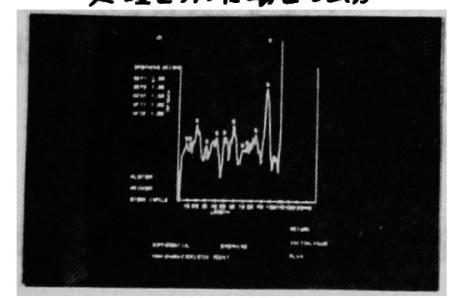

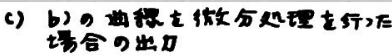

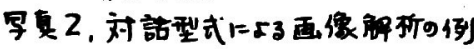

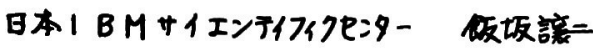

\section{1. 绡言} 早精因大学理工学部

○中村 㓪，中田夈一

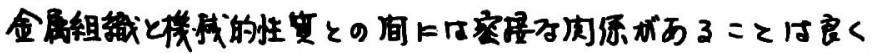

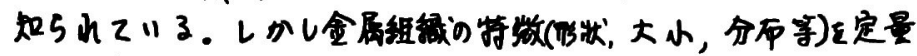
的に制定する方法が碇立レていふいようである。さラト，金属租

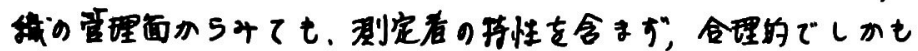

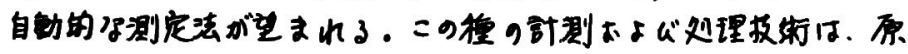

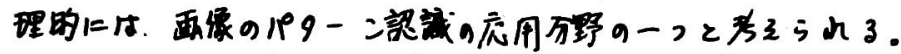

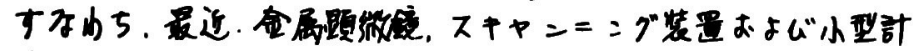

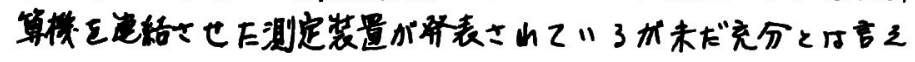
ふいようである。

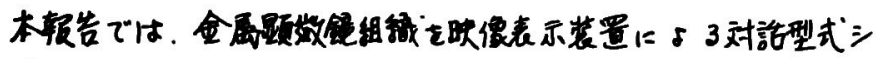

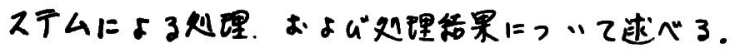

2. 实雅万清。

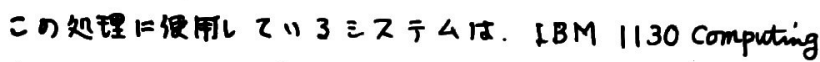
System, IBM 2310 磁婴ボイス ク, 1 BM 1403 プリンター. IBM

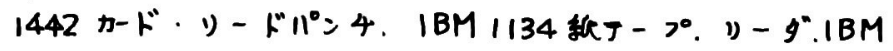
2250-M4 映像表示柿置である。まニのシステムの观理榙能と

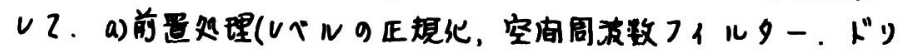

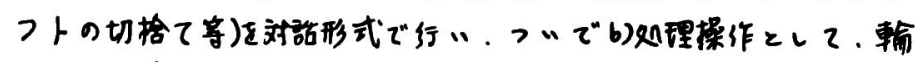

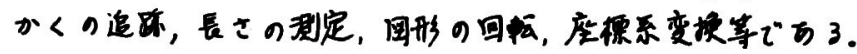

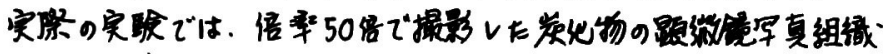

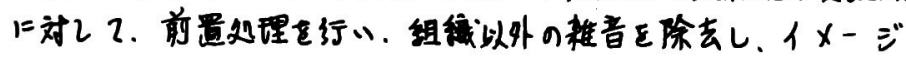
スキャナーまにリカーブリーダーから，直交座標によつて示さ

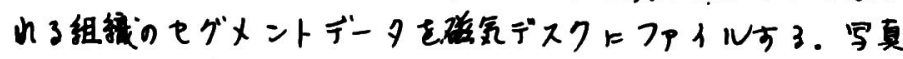

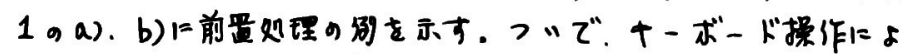

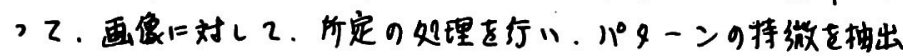
することができる。

3 实梌結果はよじ考察

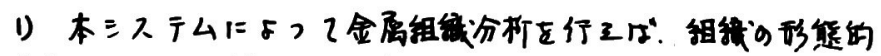
特行を man-machine対話形式で証诫することが可能でらる。

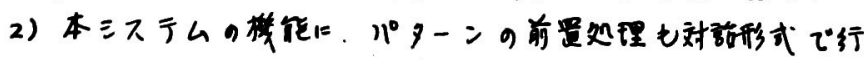

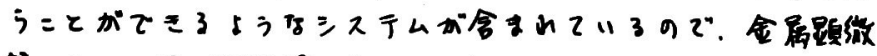

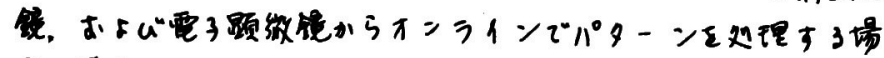
合、都合りょいものと言るる。

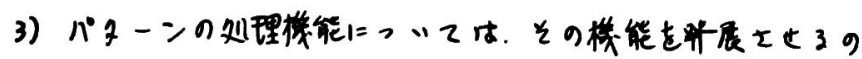

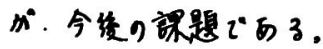




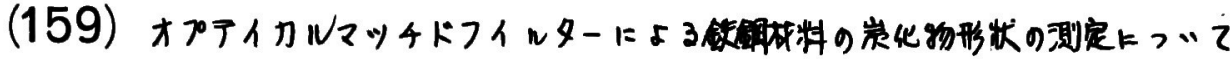

早称田大学理工学部

オリンパス光学研究部
工博口中田兑一

永井昌平, 大井上建一

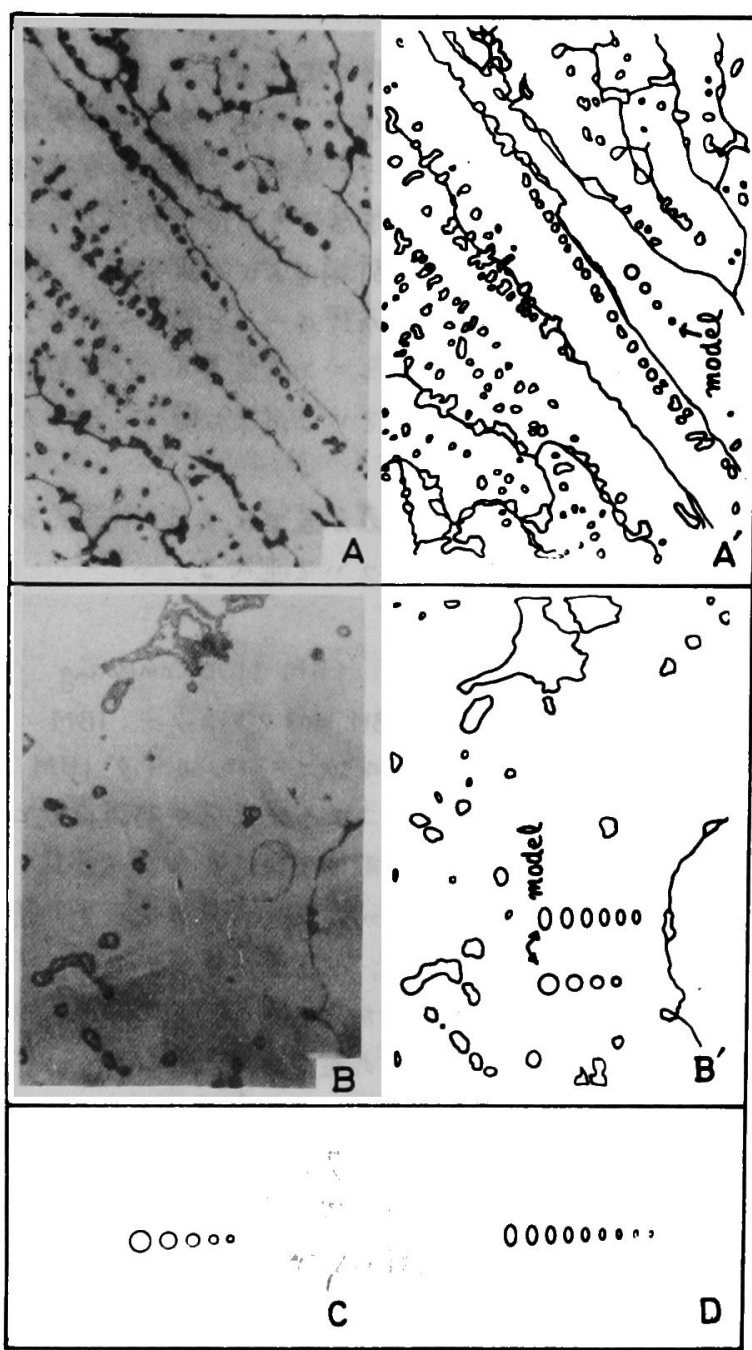

A Complex Pattern

$B$ Simple Pattern

$A^{\circ}, B^{\prime}$ Contour Patterns

C, D Reference Pattens

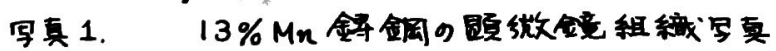
はよル゙、答照パターン
1. 継言

金属の組峨学的研等と金属の模械的性

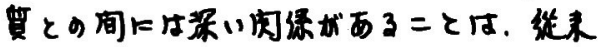
から良く知うれている。レかし名がら。た

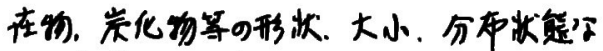

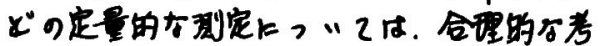

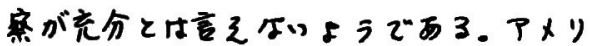
カねででは. 近年. quantitative stereology ，まЕは. quantitative metallungy»で と样する分野があり，全属租铖の定是的测

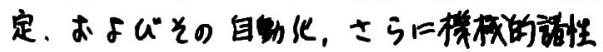
筫との相用等について核即がケされている

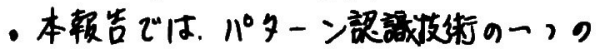
であるオプテイカルマッチドフィル夕一表

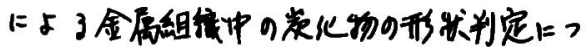
“て柃讨した。

て、实霞方去

コヒーレント光としてな. He-Nev-

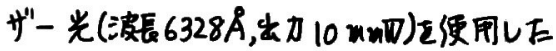

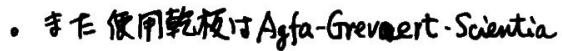

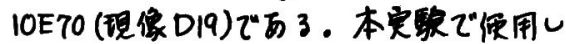

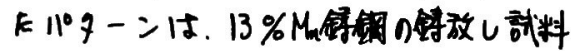
より作製レたものである。すない与肎真

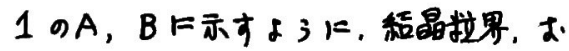

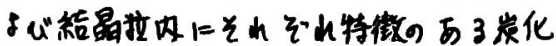

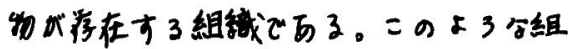
䄉上つ“2，前处理として， $A^{\prime} ， B^{\prime}=$ 示 すように. Contour 化した。 =9处理 と同時に。パターン面上の耗音の俆去。

コントラストの調整等の处理も行ラ不果 が西子、次上，C，D示すよ了な、梌 出用パターンを用意し、ニのペターンと の相主相肉を求的方法を视う。

\section{3实駅絬果なるひ考察}

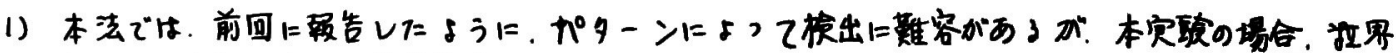

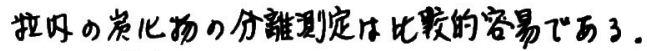

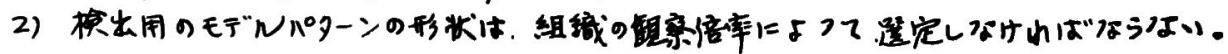




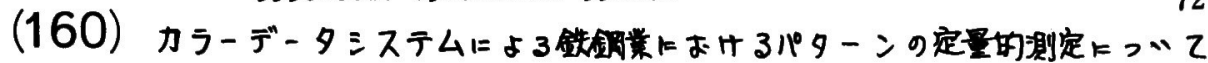

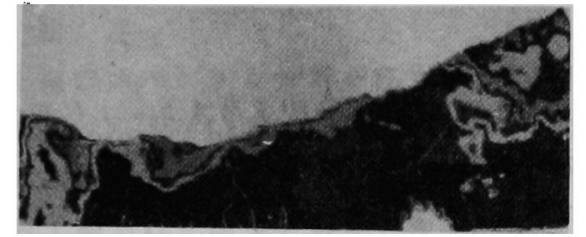

写真1. カラーデータシステムによる解析用 フレームの例

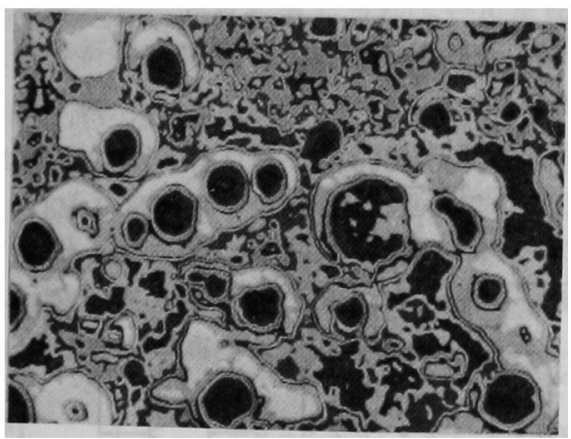

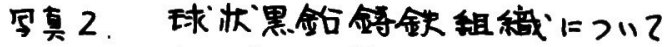
クラー化した例

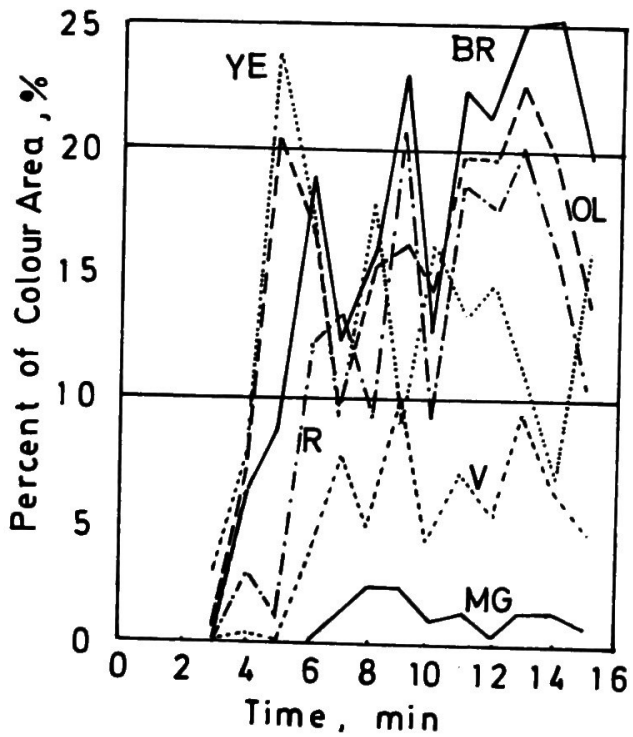

因 1. フレームの各カラー部分の面樍变化

\section{早植田大学理工学部}

(㑛) ナッフ 研究闲登部

\section{1. 绪言}

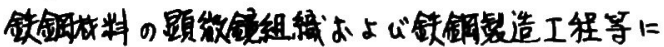
は各社の特微のあろパターンが現われることは良

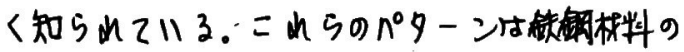

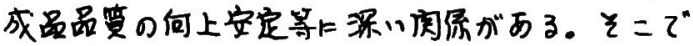

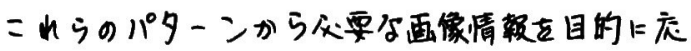
じ乍处理を行い，能率的るプロセ不解析なよば管 理等上利用することが望すいいことと思山れる。 本報告では，金禹組織の解析，铁确曒造工程に 現内川るフレームの解析等につ、2述ベる。

2 实渗方法

このカラーデターシステムは，原理的には， 測定パターンの惯度值を対数变换し、明部から 暗部までの篦团を。12色のカラーに割付ける方 法であ3。a)フレームの解析としては、时系列 に变比するフレームパターンを一定時间ジとに 撮影し、そのフレームパターンの特微を等程度 パターンに分解し．とれでれを時系列变化とし て取り出す方法を保つた。bま金属组織解 析については、特に三種頢以上の组饿が合まれ

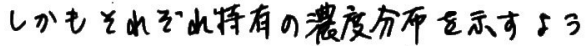

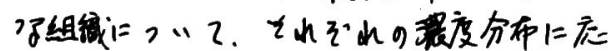
心て、カラ一で割付ける方法を行つた。

3 实䟻結果は上《考察

写真1、なよ写真乙はそ山ろ゙れ、フレ 一ム，金属組織をカラー化したヒのである 、また国1は、フレームの各力ラ一成分が 罢间とともに、特微のるる变化を示した例 である。ニいらのハターント対して，各力 ラー化レた部分の面榡率の变化を，一定方 向にスリットで走查し，走查距部になける 各力3一の面棈率变化の自己相肉, ますい”

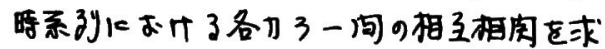
のることによつて、フレームの特微，组饿

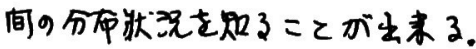




\section{1、緒言}

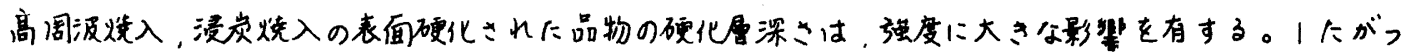

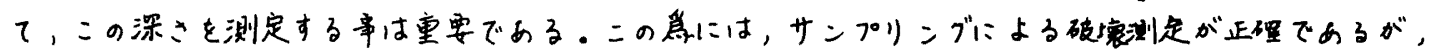

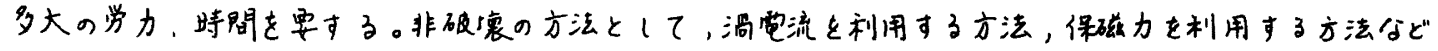
がある。本颙告は，後者の保磁力について，硬化居深さとの関係を校討し，实用に供することを磷めた

ので朝告する。

\section{2、实验方法}

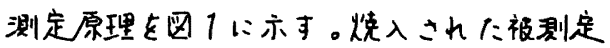
物の上に检出罢(党磁石)を置ミ,コイルに 励磁管流を流し，非硬化層部まで励磁するこ とによって，保磁力を求める。 試料は，高周波㟋入にフ川て，SCM1，

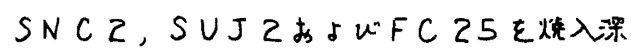

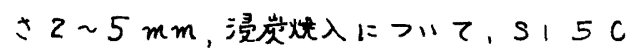
$k, S C M 22, \operatorname{sNC2} 2, \operatorname{sNCM} 23$ を浸岩深さ0.5 2.0 的とはたのを 用意した。

\section{3. 实驗䊅果}

接入深さと保磁力の閚係を，浸炭烧入の例

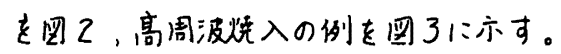

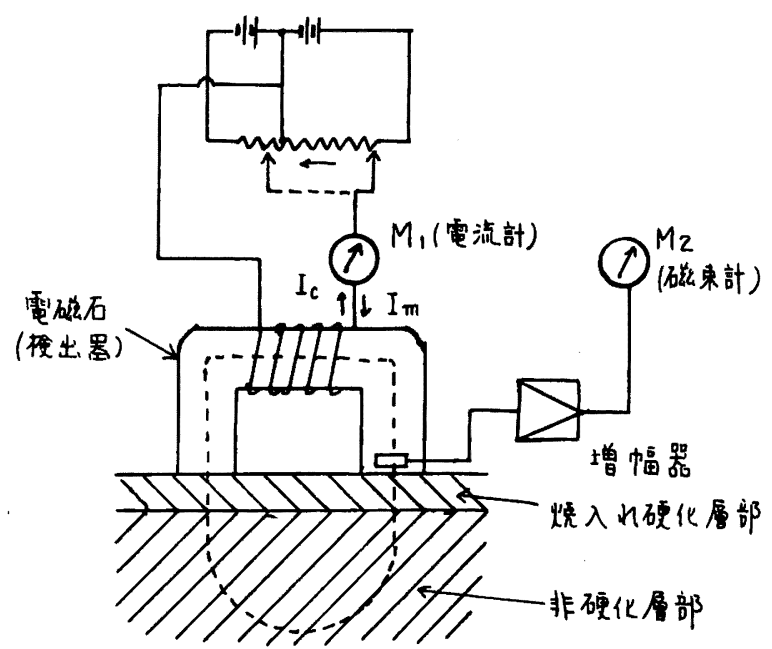

四1测定原理 れも保磁力に扵して良い相関を示し，突用に供し得ることが分った。

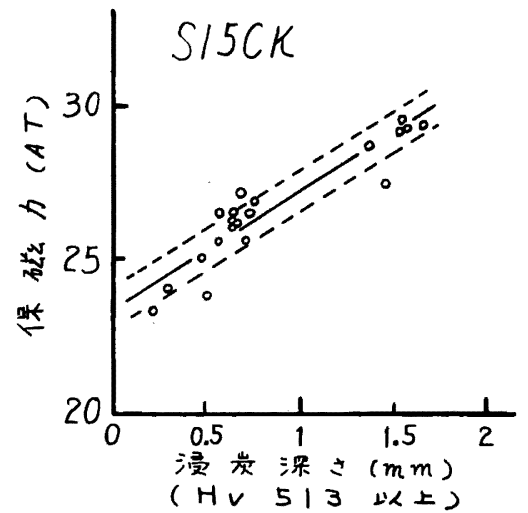

四2浸崖愤入の場合

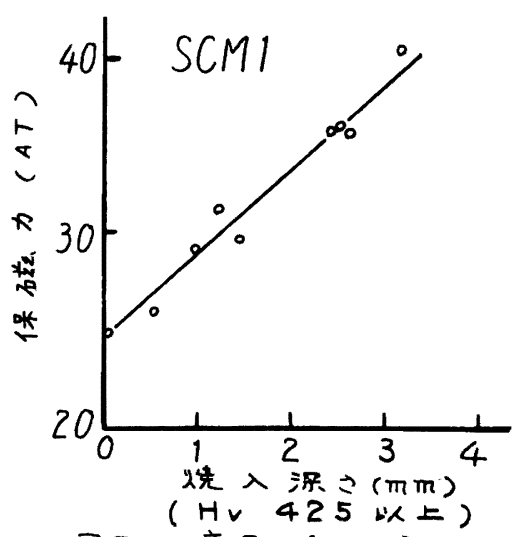

四3高周波烧入の場合 


\section{$\mathrm{Si}(\mathrm{Li})$ 半導体 X線検出素子の鉄鋼への応用} 在友金属中央技術研究所理博白岩俊男

理博 藤野允克 ${ }^{\circ}$ 山中和夫

\section{I 緒 言}

X線のスペクトル分析を行 5 為に分光器を使用せずにエネルギー分光を行 式は近年 $R \mathrm{Si}(\mathrm{Li})$ 半導体を用いる事に上り急速に進歩してをた。

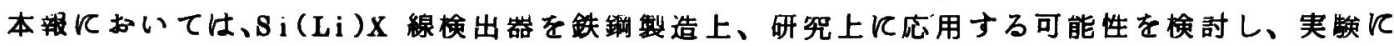
上って得られた結果と適用した実施例およびその効果を論ずる。

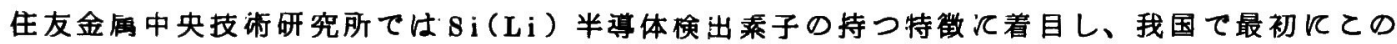
素子を俞入し、一般に信じられていた定性分析用或いは簡易分析用以外飞迅速分析、オン・ラィ ン定量分析等の用途への可能性を見出し、今后の計测技術面で発展を示するのであ。

I 実 跲

使用した Si（Li) 素子はORTEC 製真空用の型て、実䮖は次の方法について行われた。

(1) SEM（日本電子 J SM - 2 型）ての電子線励起 X 線测定

(2) 営光 X 線分析への応用 (島津 $F X-402$ 人装着)

(3) $\mathrm{X}$ 線回折への応用 (埋学 D-型へ装着)

装置の概観を写真 1 亿示す。
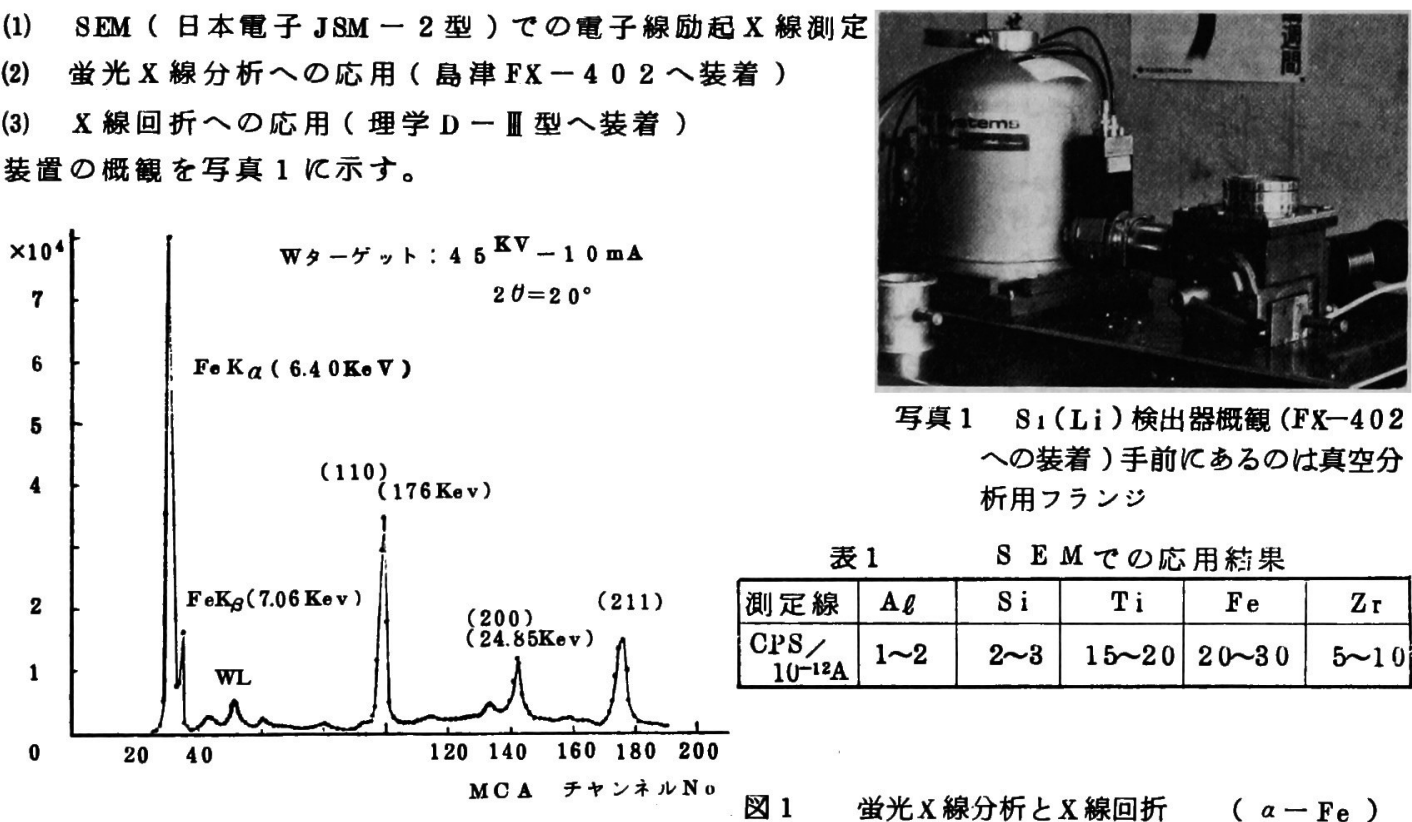

写真 $1 \quad S_{1}(L i)$ 検出器概観 $(F X-402$ への装着) 手前にあるのは真空分 析用フランジ

表1 S E M C应用絬果

\begin{tabular}{|c|c|c|c|c|c|}
\hline 測足線 & $\mathrm{A}_{\boldsymbol{\ell}}$ & $\mathrm{Si}$ & $\mathrm{Ti}$ & $\mathrm{Fe}$ & $\mathrm{Z}_{\mathrm{r}}$ \\
\hline $\begin{array}{c}\mathrm{CPS} / \mathrm{S}^{-12 \mathrm{~A}} \\
\mathrm{IU}\end{array}$ & $1 \sim 2$ & $2 \sim 3$ & $15 \sim 20$ & $20 \sim 30$ & $5 \sim 10$ \\
\hline
\end{tabular}

II結 果

(1) 8 EMへD応用

方法沬通常使用する電流( $\left.10^{-12} \mathrm{~A}\right)$ て直接非分光にて測定した。測定結果を表 1 亿示す。

(2) 蛍光 X 線分析への応用

蛍光 $\mathrm{X}$ 線分析ての定量結果は分光式と変らず、全元素を $5 \sim 30$ 秒にて測定でる。ての方法 に上りオン・ライン分析、炬前分析、焼結鉱分析す実用化した。

被膜厚測定は亚鈶鉄板、ブリキ、塗膜厚、テーブ膜厚測定を行い良好な結果を得た。

(3) X 線回折

白色 X 線を使用して回折線の全ラインを同時測定し、併せて元素分析をる行5。結果を図 1 亿示す。 
'72-S 166

（163） 3 木引用超音没伸管装置。孰作

一超音波神管の研究 (II) -

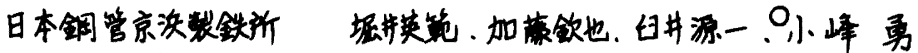

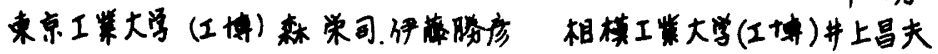

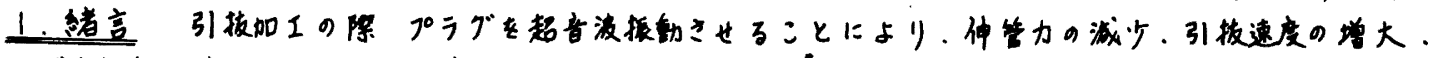

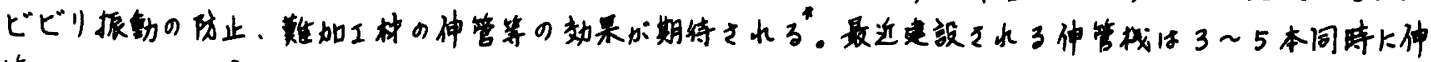

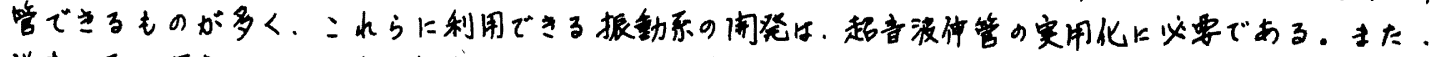

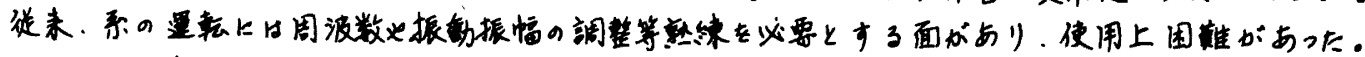

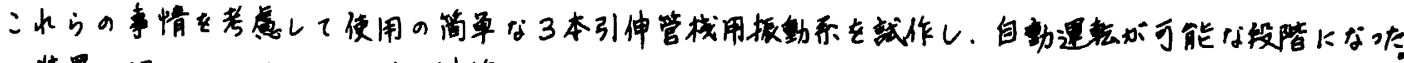

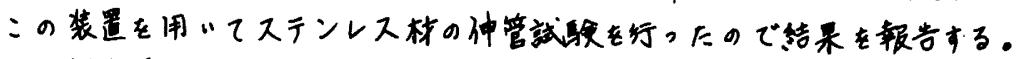

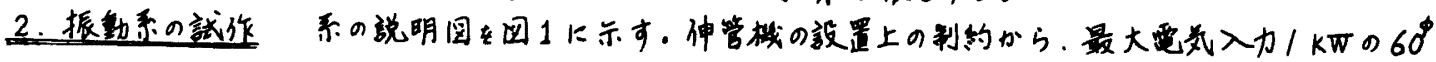

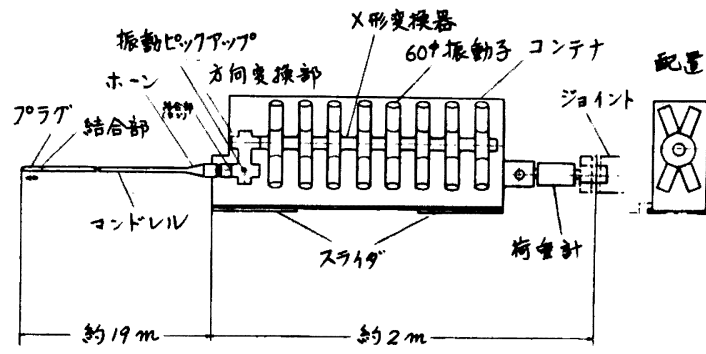

园1超音没伸管装是

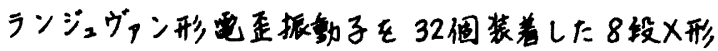
变换器使用し，登生した強力な集来超音波的的.20

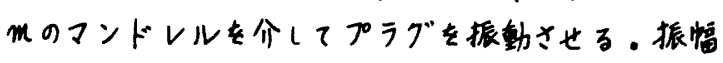

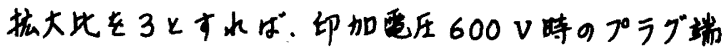
鸟区勃力生约 2 で．伸管力20大程度の伸管まで超音

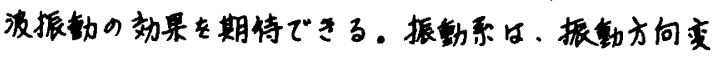

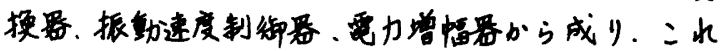
らは正师透登振ループを形成している。系の共振周

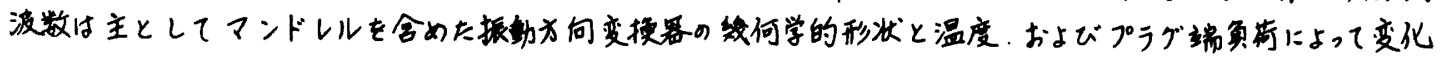

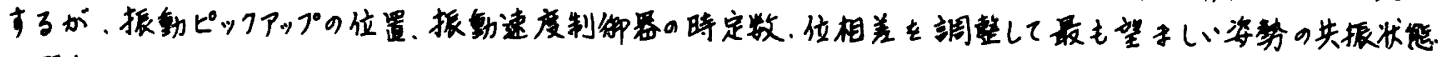

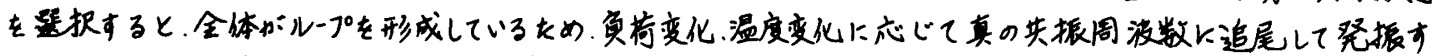

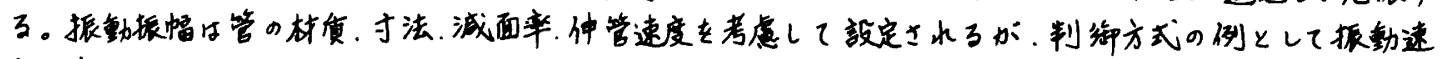
度と伸管速度の此を一定にした方式を粙用した。

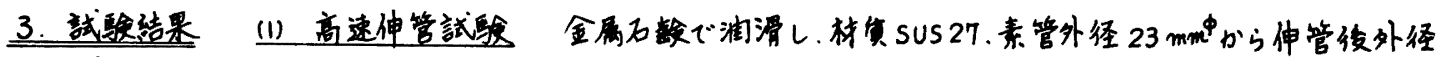

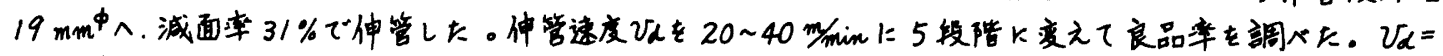
20 ，25，30 m/minで7本伸管し、全て良品でおった。35，40 m/minでは5本中良品/でおり、この結果から。

この伸管条件に对し超音波振動を利用すると、30 m/minまで安定に作学できることがかか。

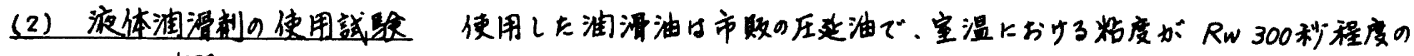

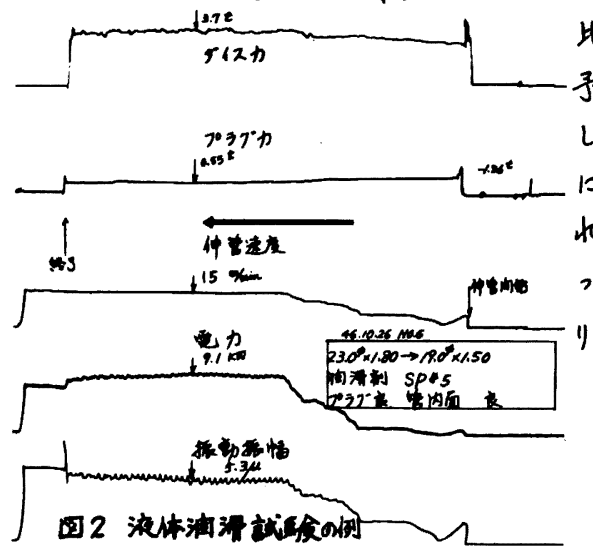
比校的低炶度のものである。管寸法は高进伸管の场合と同じで。

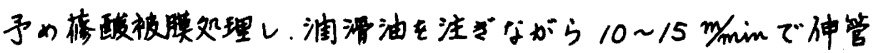

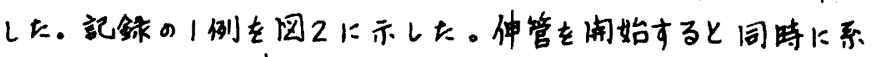
に要力が印加これ伸管速度に比例して、プラゲ报勒速度が制御々 水了。伸管数17本中，良吕16，烧付/で良吕率は95\%であ

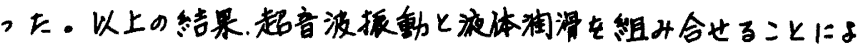

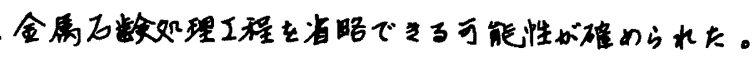
*文献

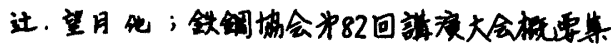
P $258 \sim 259$ 


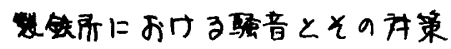

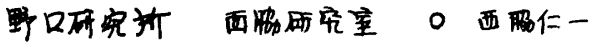

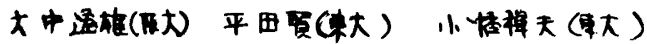

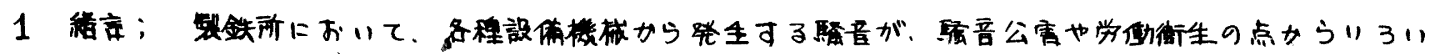

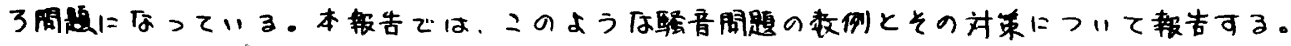

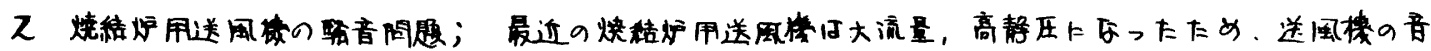

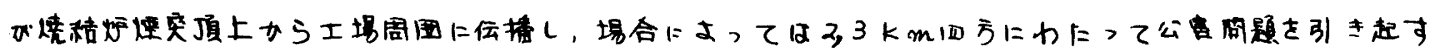
ことがある・:の场合、送国 楼出口倒上消音然巨設置する ことにより周题を解決できる 一四ははとのー例で， $5100 \mathrm{kw}, 1700 \mathrm{~ms} / \mathrm{min}$ -1400 mxAg a羊同杸

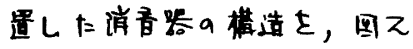
はとの乵米を示にている。

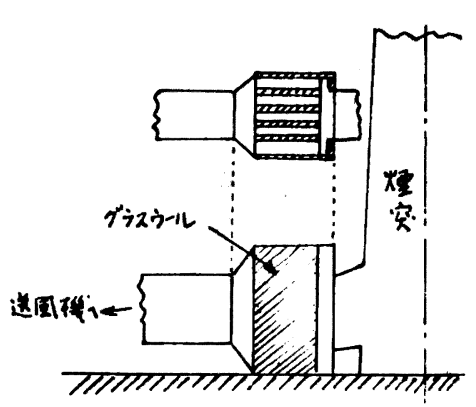

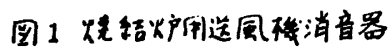

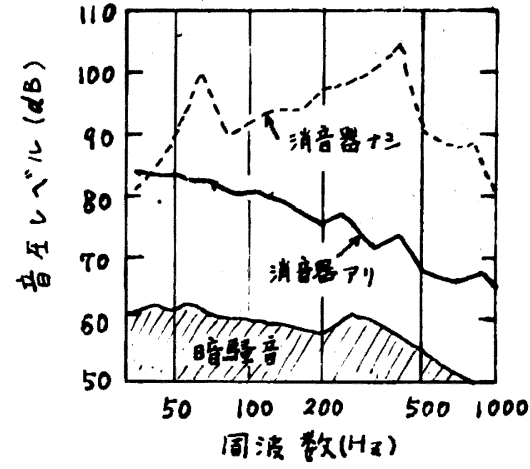

因2、洷突通下での消音効果

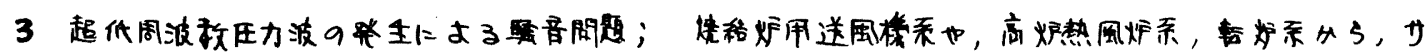

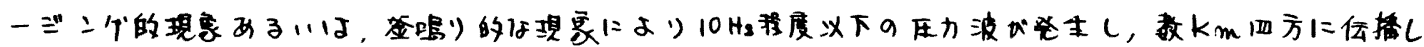

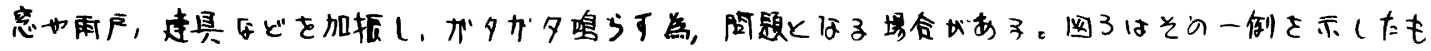

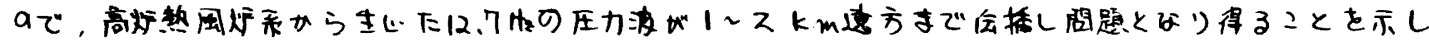

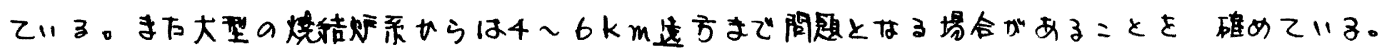

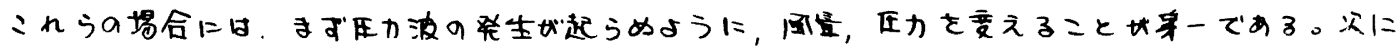

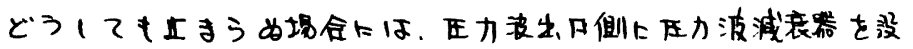

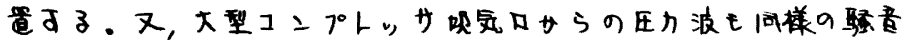

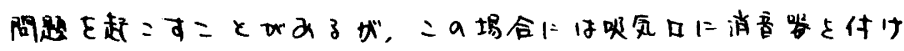
れぱよル。

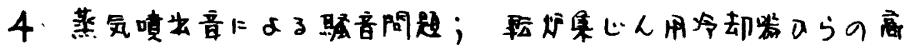

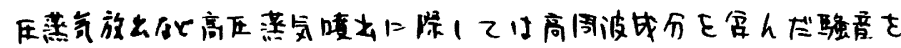

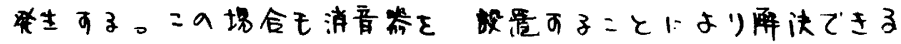

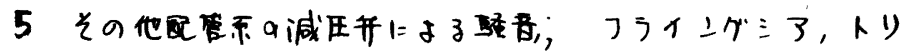

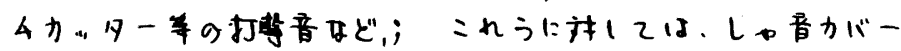

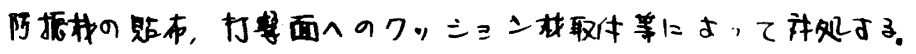

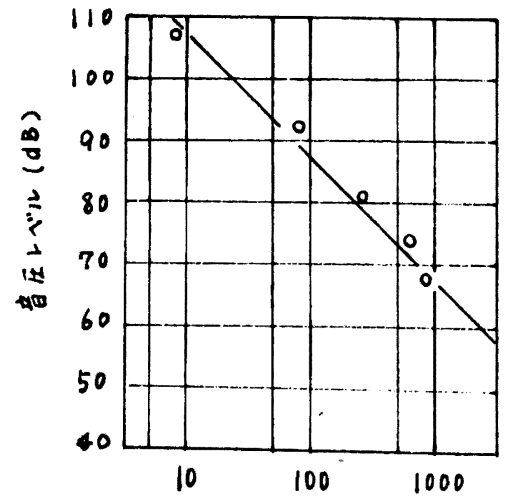

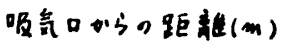

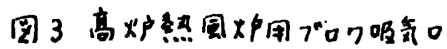
dり $2312.7 \mathrm{~Hz}$ ，压力波 


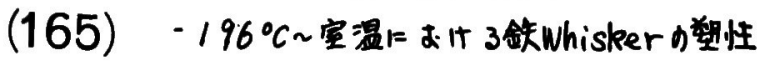

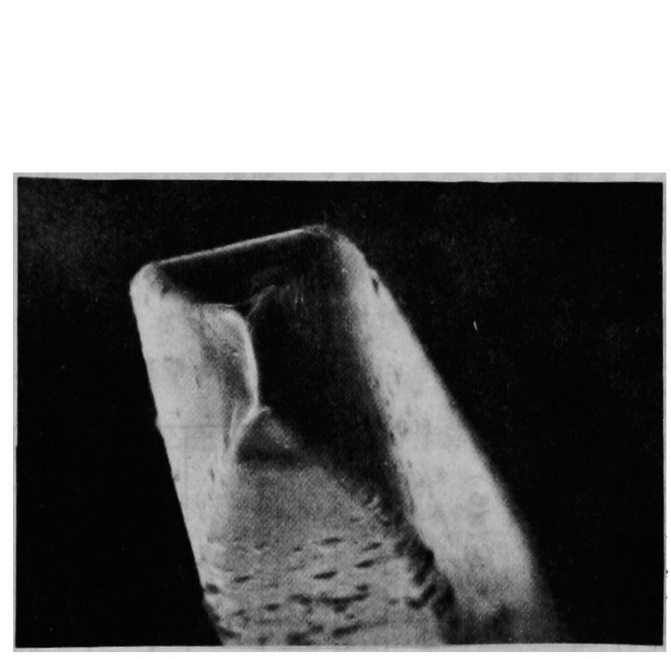

写真1。破面の状熊 (走查型西子寡微鏡による 観案) 試料, $\langle 100\rangle$ 型 部验温度 $-53^{\circ} \mathrm{C}$

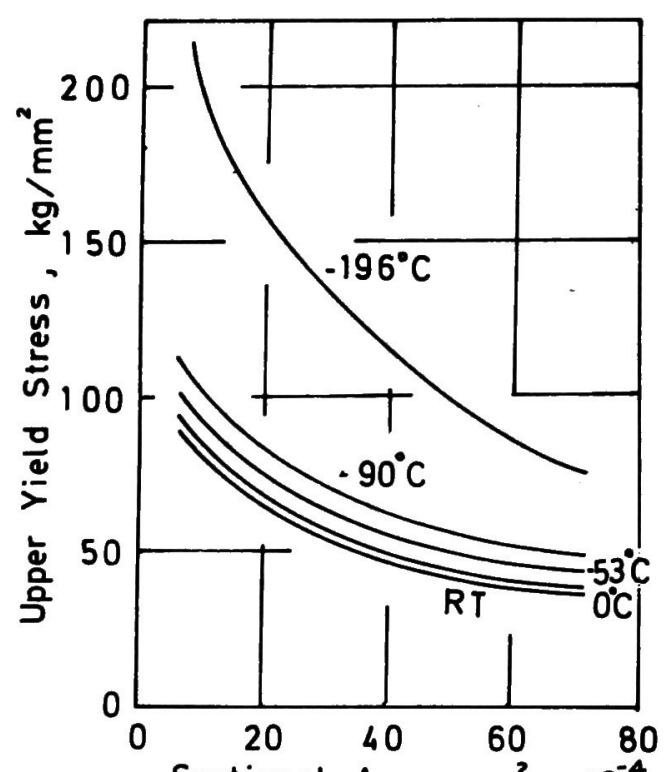

Sectional Area. $\mathrm{mm}^{2} \times 10^{-4}$

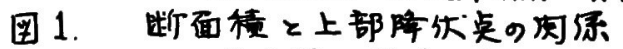

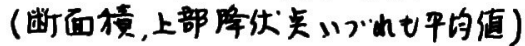

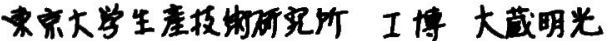

早稳田大学理工学部

\section{1 緒言}

工博。中田栄一，二是一考

後藤则夫

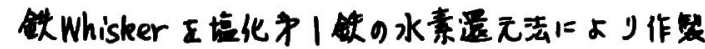

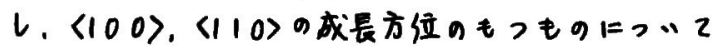

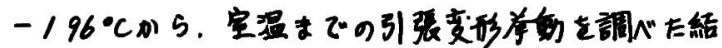
果鼓告才了。

\section{2. 突駼方法}

上記のようを方法で作笠レに铁 Whister のうち，

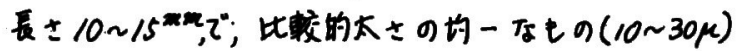

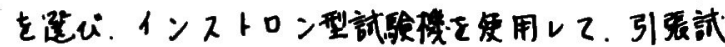

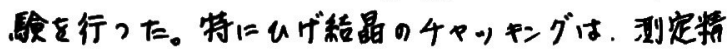

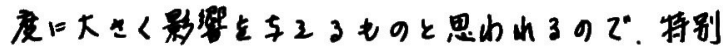

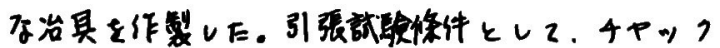

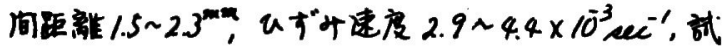

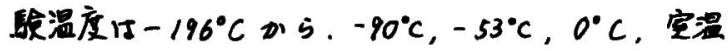
までの5段階である。

3. 实弱結果むよ代考察

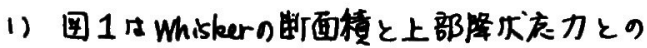

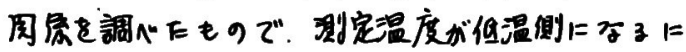
したがい上部降状応かは上显する。さうに下部降

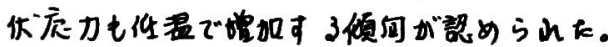

2) 甽面积の小之、Whisker では降优点によす 了态加降下が影著であり，低温でも同㧺ほ二てが 訆りら山た。

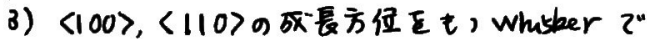

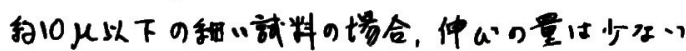
詣向がある。

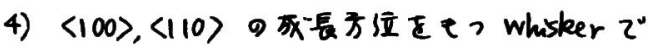

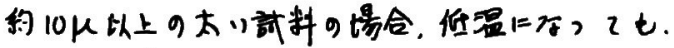

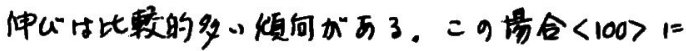

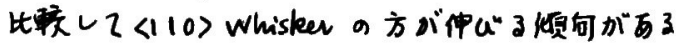

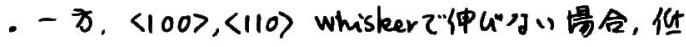

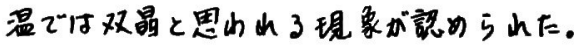

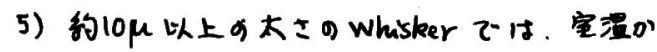

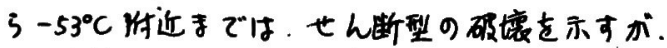

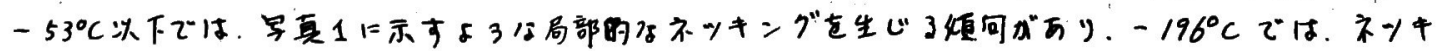

ンブの量が減少する倾向が锭察された。 


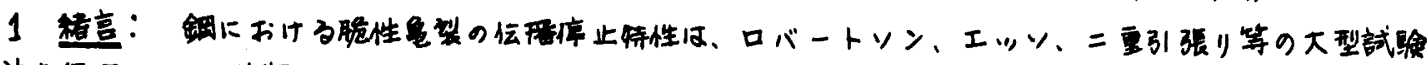

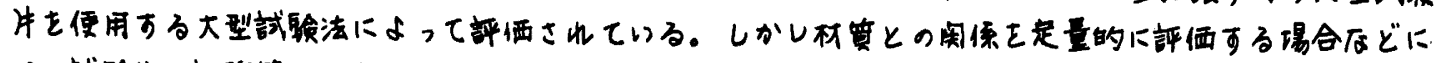

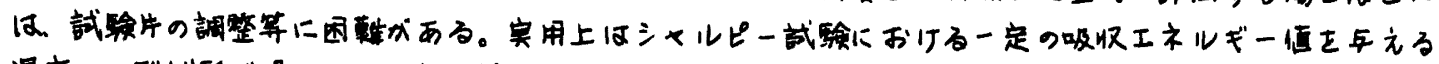

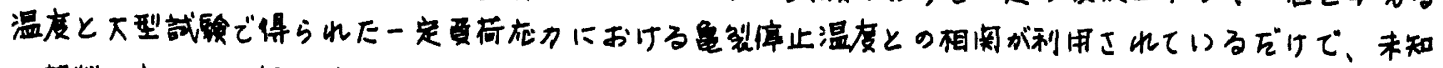

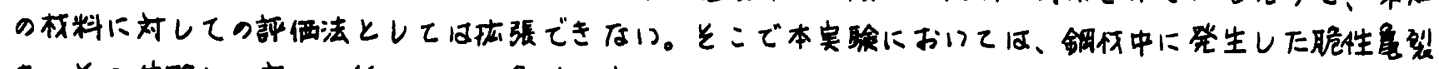

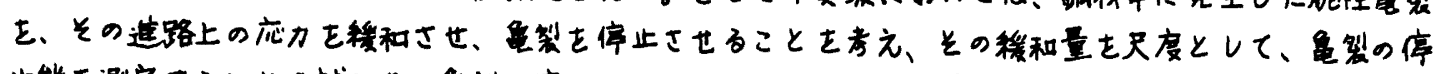

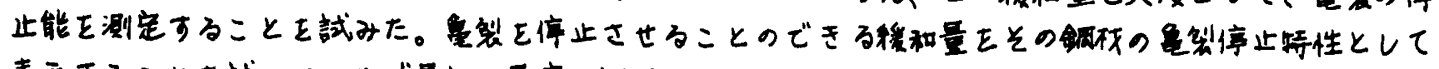

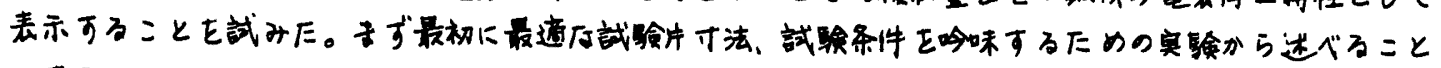
にする。

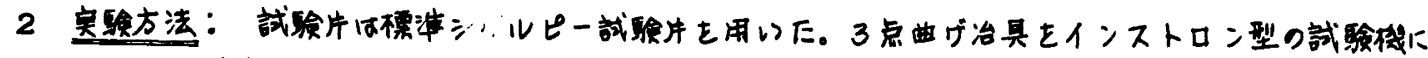

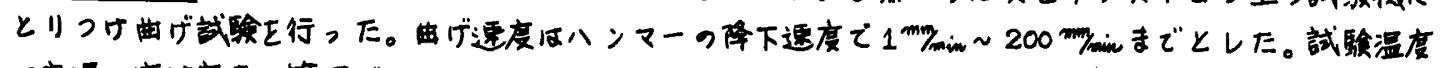

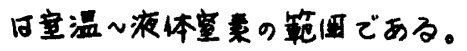
広カの楥和をちえるたのに、国に 亦すような位贵にドリルでュタで

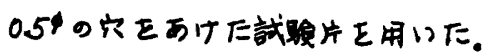
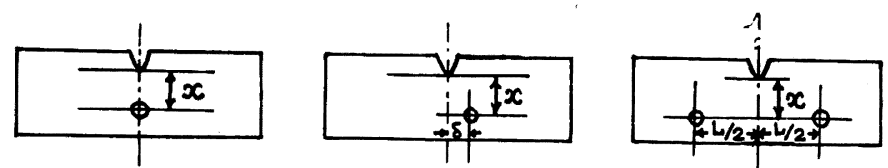

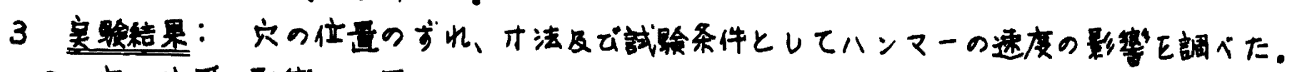

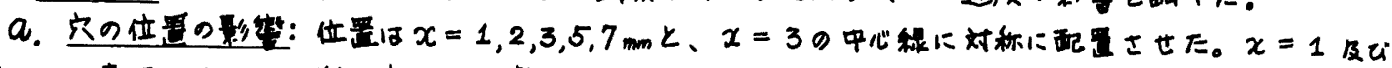

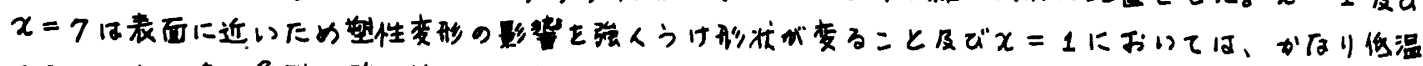

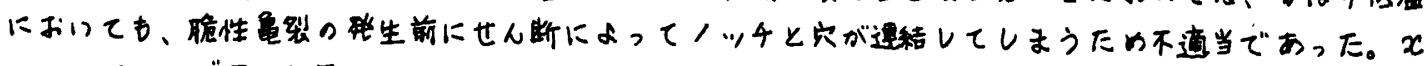

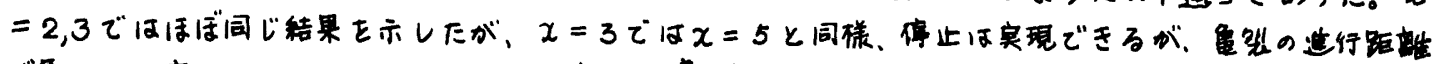

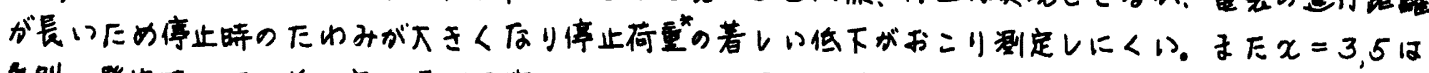

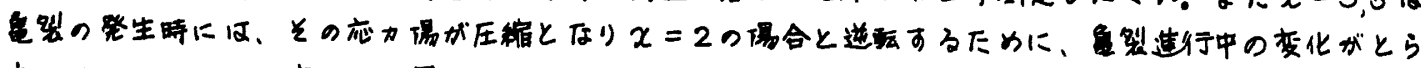

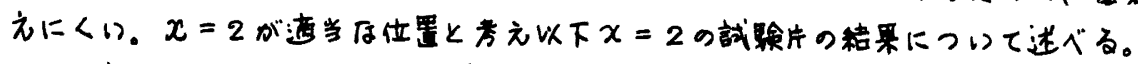

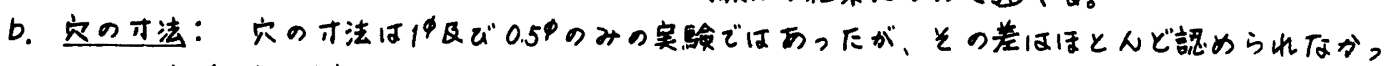
た。よって以後伂の穴の武駼片について迷ベる。

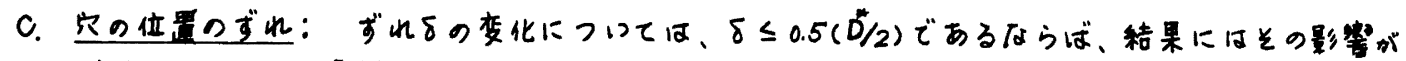

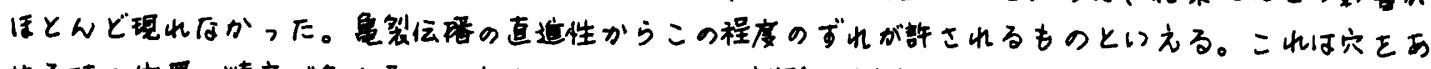

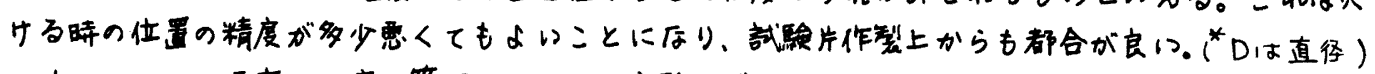

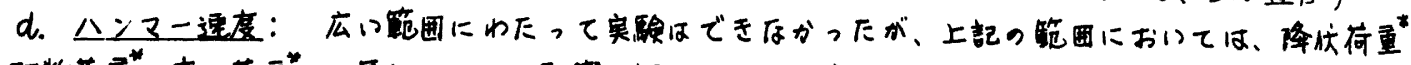

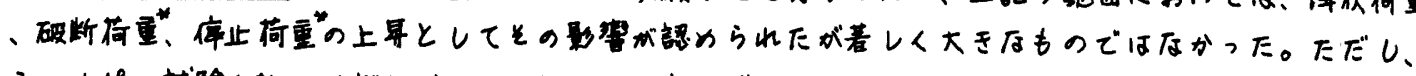

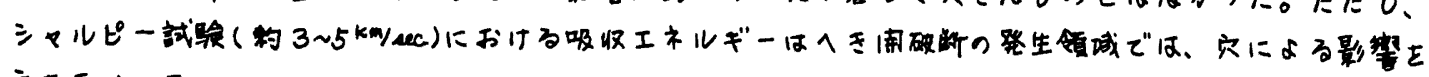
亦さなかった。

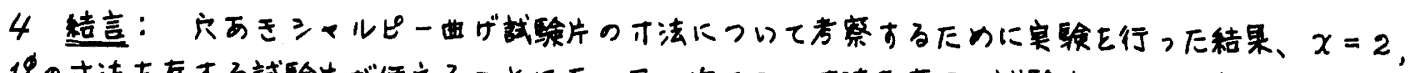

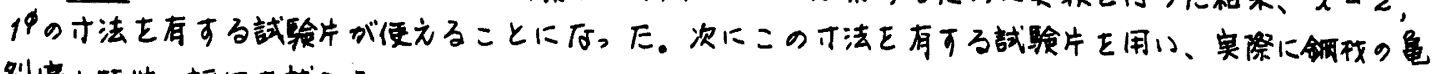
裂停止特性の評洒飞武みる。

*“穴ちき三メルピー曲切試博の㐫用”におりる因参照 